\title{
Tofuyo (fermented soybean food) extract prolongs the survival of mice infected with influenza virus
}

\author{
AKIKAZU SAKUDO $^{1}$ and MASAYASU SESOKO ${ }^{2}$ \\ ${ }^{1}$ Laboratory of Biometabolic Chemistry, School of Health Sciences, Faculty of Medicine, University of the Ryukyus, \\ Nishihara, Okinawa 903-0215; ${ }^{2}$ RyuKyu-Cement Co., Ltd., Urasoe, Okinawa 901-2123, Japan
}

Received August 28, 2012; Accepted October 17, 2012

DOI: $10.3892 /$ br.2012.29

\begin{abstract}
Fermented soybean, known as tofuyo, is a traditional food in Okinawa (Japan). Tofuyo extract is obtained from the supernatant of fermented soybean after homogenization, filtration and centrifugation. In this study, we analyzed the in vitro effect of tofuyo extract on influenza virus using immunochromatography of the influenza virus nucleoprotein (NP). The results showed that tofuyo extract does not have a strong inhibitory effect on NP. This finding was confirmed by an assay for virus activity using embryonated eggs. To investigate the potential anti-influenza virus activity of tofuyo in vivo, 5 nude mice (BALB/cSlc-nu/nu) were administered drinking water supplemented with tofuyo extract the day prior to intranasal inoculation with influenza virus, while the control group (5 mice) was administered tofuyo extract-free water. Control group mice $(40 \%)$ were dead within 14 days, while the mice that were administered water containing tofuyo extract survived. Nutrient component analysis showed that tofuyo extract contains proteins, carbohydrates, vitamins and minerals that provide nutritional value, which may help to maintain good health.
\end{abstract}

\section{Introduction}

Tofuyo (fermented soybean food) is a traditional local specialty product of Okinawa, Japan (Fig. 1), and it is believed that the nobles of Okinawa during the Ryukyu Dynasty period identified tofuyo as a nutritious food good for recovery from illness. Tofuyo is prepared by fermenting tofu in a mixture of alcoholic, sake-like beverage (known as awamori) along with rice malt and red yeast, which gives tofuyo its distinctive red color. It has been demonstrated that tofuyo contains a variety of functional components and that it has numerous properties as a healthy food, including protection of the stomach wall

Correspondence to: Dr Akikazu Sakudo, Laboratory of Biometabolic Chemistry, School of Health Sciences, Faculty of Medicine, University of the Ryukyus, 207 Uehara, Nishihara, Okinawa 903-0215, Japan

E-mail: sakudo@med.u-ryukyu.ac.jp

Key words: tofuyo, awamori, influenza, fermented food, healthy food and mucous membranes, as well as inhibition of cholesterol synthesis $(1,2)$.

Influenza occurs every winter and the virus is transmitted through the mucous membrane of the nose and the respiratory tract. Therefore, the aim of this study was to investigate whether or not tofuyo ingestion has an effect on influenza infection. As a result, an animal experiment was conducted to determine the effects of tofuyo extract on the influenza virus and influenza infection in vitro and in vivo; tofuyo extract nutrient components were also analyzed.

\section{Materials and methods}

Preparation of tofuyo extract. Tofuyo prepared from red and yellow kojis (2) was supplied by Benihama Co., Ltd. (Okinawa, Japan). Tofuyo was suspended in 3 volumes of distilled water, homogenized, and then mixed at room temperature for $1 \mathrm{~h}$. The mixture was centrifuged at $12,000 \mathrm{x} \mathrm{g}$ for $15 \mathrm{~min}$, and the resulting precipitate was removed. The supernatant was filtered, and the filtered solution was used as the tofuyo extract.

Influenza virus. Influenza virus strain PR8 [A/Puerto Rico/8/34 (H1N1)] was used in this study (3).

In vitro analysis. The culture supernatant $\left(3.16 \times 10^{14} \mathrm{TCID}_{50} / \mathrm{ml}\right)$ of Madin-Darby canine kidney (MDCK) cells infected with influenza virus strain PR8 was mixed with tofuyo extract and incubated. Changes in the amount of nucleoprotein (NP) of influenza virus were measured using immunochromatography (ESPLINE ${ }^{\circledR}$ Influenza A\&B-N, Fujirebio, Inc., Tokyo, Japan). Similarly, changes in the sensitivity of embryonated chicken eggs to influenza virus were analyzed by injecting the above mixture into 12-day-old embryonated chicken eggs.

In vivo analysis. Influenza virus strain PR8 was inoculated into embryonated chicken eggs. Influenza virus-infected allantoic fluid was collected $48 \mathrm{~h}$ following incubation [a unit for hemagglutinin (HA) value of $10^{9}$ ], and a $10^{5}$-fold diluted solution of allantoic fluid was nasally inoculated into nude mice (BALB/cSlc-nu/nu) by inhalation through the nose under anesthesia. For the tofuyo extract-administered group, tofuyo extract solution, which was prepared by adding $1 \mathrm{ml}$ of extract to $200 \mathrm{ml}$ of water, was administered as drinking water from the day prior to inoculation. Tofuyo extract-free water was 


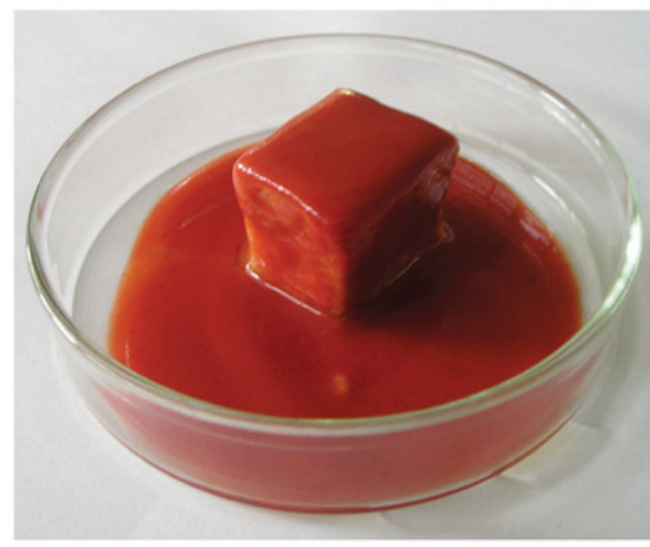

Figure 1. Tofuyo prepared from red and yellow kojis.

administered to the control group. Following inoculation, mice were observed for changes in weight against time. Lungs were then collected from the mice that died and those that survived until 14 days following inoculation. Each collected lung was homogenized to prepare a $0.5 \%$ homogenate, and the amount of NP of the influenza virus was measured by immunochromatography (ESPLINE ${ }^{\circledR}$ Influenza A\&B-N). The animals were treated in accordance with the procedures approved by the Animal Experiment Committee of the University of Ryukyus (Nishihara, Japan). This experiment was permitted by the Guidelines for the Care and Use of Laboratory Animals, approved by the Animal Experiment Committee of the University of Ryukyus (permit no. 5465).

Nutrient component analysis. According to the Analytical Manual for Standard Tables of Food Composition in Japan (4) and the Tables of Food Composition (5), the content of energy, water, protein, lipid, carbohydrate, ash, sodium, potassium, calcium, magnesium, phosphorus, iron, zinc, copper, manganese, vitamins $\mathrm{B}_{1}, \mathrm{~B}_{2}$ and $\mathrm{B}_{6}$, soluble, insoluble and total dietary fibers, sodium chloride equivalent and alcohol was measured in the tofuyo extract. In addition, the content of arginine, lysine, histidine, phenylalanine, tyrosine, leucine, isoleucine, methionine, valine, alanine, glycine, proline, glutamic acid, serine, threonine, aspartic acid, tryptophan as well as cysteine and cystine was measured using amino acid autoanalysis and high-performance liquid chromatography.

\section{Results}

In vitro effect of tofuyo extract on nucleoprotein and influenza virus infection. The culture supernatant of MDCK cells infected with influenza virus strain PR8 was mixed with tofuyo extract, phosphate-buffered saline (PBS) or $8.5 \%$ ethanol at a dilution of $1: 9$, and incubated at $37^{\circ} \mathrm{C}$ for $30 \mathrm{~min}$. The amount of NP in the influenza virus was then compared by immunochromatography. As a result, incubation with $8.5 \%$ ethanol and tofuyo extract showed no major differences in the amount of NP compared to PBS (Fig. 2).

Following incubation the above samples were inoculated into the allantoic cavity of embryonated chicken eggs, and allantoic fluid was collected $48 \mathrm{~h}$ later. Sensitivity to the virus
A

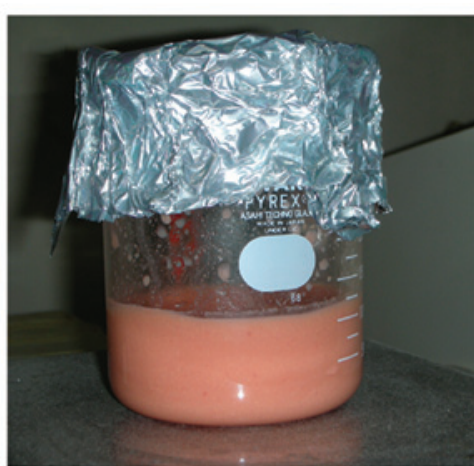

B

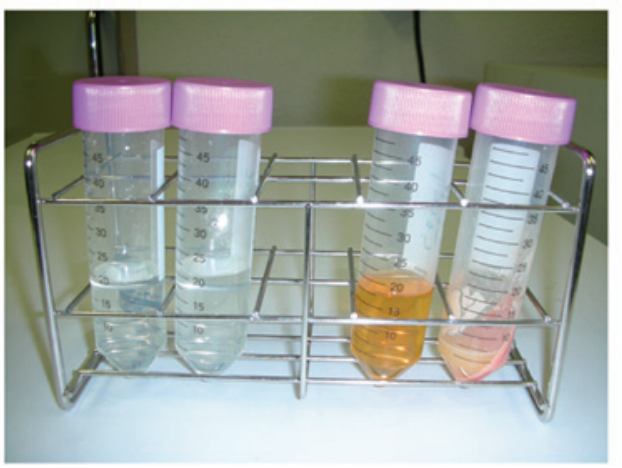

C

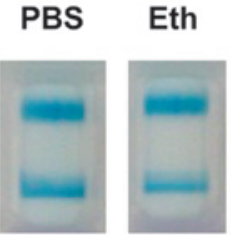

Tofu

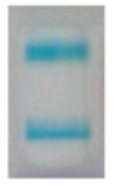

-Reference

-Influenza A virus NP

Figure 2. In vitro effect of tofuyo extract on nucleoprotein (NP) of influenza virus is shown. (A) Tofuyo diluted with distilled water and homogenized. (B) Left to right: phosphate-buffered saline (PBS), 8.5\% ethanol, supernatant of tofuyo filtered and centrifuged, pellet of tofuyo filtered and centrifuged. (C) Cell culture medium of cells infected with influenza virus strain PR8 was mixed with the indicated samples. NP of influenza virus was detected by immunochromatography (PBS, PBS + influenza virus, $37^{\circ} \mathrm{C}$ for $30 \mathrm{~min}$; Eth, $8.5 \%$ ethanol + influenza virus, $37^{\circ} \mathrm{C}$ for $30 \mathrm{~min}$; Tofu, tofuyo extract + influenza virus, $37^{\circ} \mathrm{C}$ for $30 \mathrm{~min}$ ). The reference line verified the success of the assay. The intensity of the influenza A virus NP line indicated the quantity of influenza A virus NP. Modified from Figs. 1 and 2 in Sakudo and Sesoko (6) with the permission of the Fuji Foundation for Protein Research.

after each treatment was compared by measuring the amount of NP of the influenza virus in the allantoic fluid using immunochromatography. As a result, it was demonstrated that treatment with $8.5 \%$ ethanol reduced the activity of the influenza virus, while the tofuyo extract did not reduce the infectivity of the virus (Fig. 3). Thus, this indicated that low ethanol in the tofuyo extract did not reduce the activity of the influenza virus.

Tofuyo extract prolongs survival of mice and delays decrease in body weight of mice caused by influenza virus infection. A $10^{5}$-diluted solution of allantoic fluid infected with influenza virus strain PR8 was nasally inoculated into nude mice. The mice were then reared for 14 days and changes in their weight were measured. In the group administered the water-containing tofuyo extract from the day prior to inoculation, the mice $(5 / 5)$ survived, while in the control group where mice were administered tofuyo extract-free water, 2 mice died 


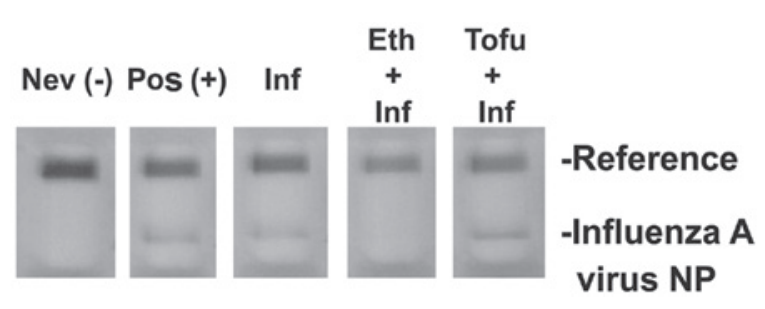

Figure 3. In vitro effect of tofuyo extract on influenza virus infection is shown. Cell culture medium of cells infected with influenza virus strain PR8 and treated by the indicated procedures was injected into embryonated eggs and incubated for $48 \mathrm{~h}$. Allantoic fluid was collected and subjected to immunochromatography. The reference line verified the success of the assay. The intensity of influenza A virus NP line indicated the quantity of influenza A virus NP. Left to right: Nev (-), no influenza virus; Pos (+), no treated influenza virus; Inf, influenza virus incubated at $37^{\circ} \mathrm{C}$ for $30 \mathrm{~min}$; Eth $+\mathrm{Inf}, 8.5 \%$ ethanol + influenza virus incubated at $37^{\circ} \mathrm{C}$ for $30 \mathrm{~min}$; Tofu + Inf, tofuyo extract + influenza virus incubated at $37^{\circ} \mathrm{C}$ for $30 \mathrm{~min}$. Modified from Fig. 3 in Sakudo and Sesoko (6) with the permission of the Fuji Foundation for Protein Research.

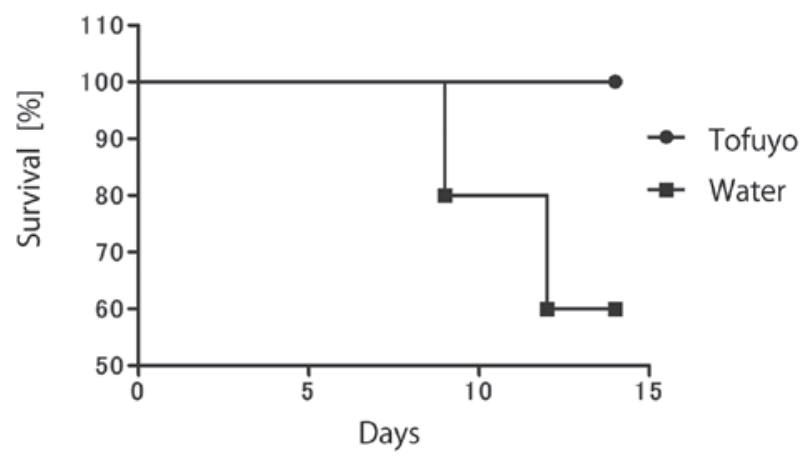

Figure 4. Tofuyo extract prolongs the survival of mice infected with influenza virus. Graph shows the survival percentage of two groups of nude mice (BALB/cSlc-nu/nu) after intranasal infection with influenza virus [A/Puerto Rico/8/34 (H1N1)]. The control group was administered tofuyo extract-free water, whereas the study group was administered watercontaining tofuyo extract.

on days 9 and 12 following inoculation, and 3/5 mice survived (Fig. 4). In addition, comparing weight changes, weight loss was significantly smaller in the tofuyo extract-treated group compared to the control group $(\mathrm{P}<0.05$, paired Student's t-test $)$ (Fig. 5).

Tofuyo extract does not inhibit proliferation of the influenza virus in lung, but exhibits indirect protective effects against influenza virus infection. Immunochromatography of the influenza virus NP in the lungs from dead mice showed that NP of the influenza virus was expressed in the dead mice (Fig. 6), suggesting that the mice died of influenza virus infection. In addition, NP was detected in $2 / 5$ mice of the tofuyo extract-treated group and $3 / 5$ mice of the control group in mice sacrificed 14 days following inoculation. Therefore, tofuyo extract did not have any direct effects on the influenza virus or its production, while it had indirect protective effects against influenza virus infection.

Nutrient component and amino acid analyses exhibits healthpromoting effects. Nutrient component analysis was conducted to investigate the mechanisms underlying the anti-influenza

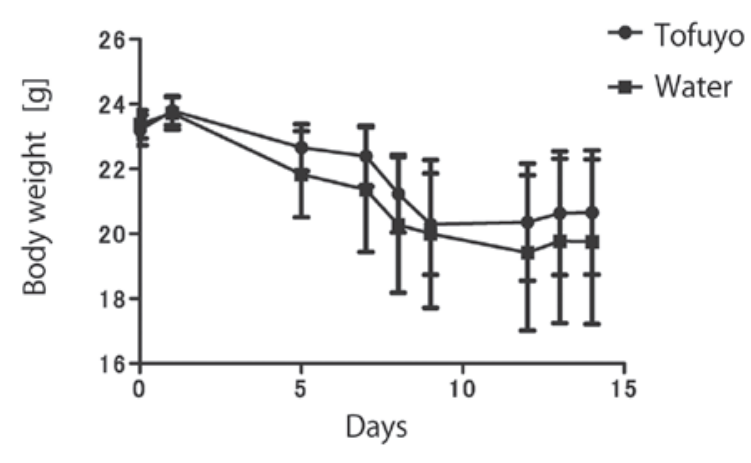

Figure 5. Tofuyo extract significantly delays the decrease in body weight caused by infection with influenza virus [A/Puerto Rico/8/34 (H1N1)] in mice $(\mathrm{P}<0.05$, paired Student's t-test). Tofuyo, nude mice (BALB/cSlc-nu/ $n u)$ administered tofuyo extract-containing water; Water, nude mice administered tofuyo extract-free water.

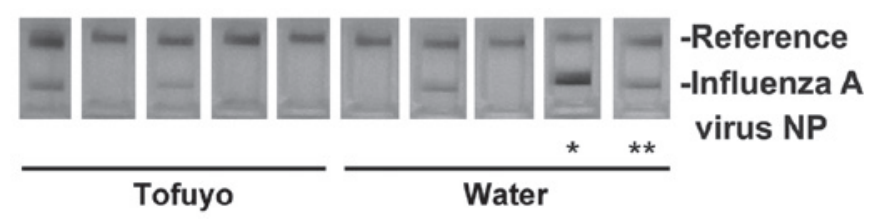

Figure 6. Tofuyo extract does not inhibit proliferation of influenza virus in lung. Lungs of nude mice (BALB/cSlc-nu/nu) infected with influenza virus [A/Puerto Rico/8/34 (H1N1)] were collected and subjected to immunochromatography. Tofuyo, mice administered tofuyo extract-containing water; Water, mice administered tofuyo extract-free water. Mice died on *day 9 and *** 12 . The remaining mice were sacrificed on day 14 .

virus effect of the tofuyo extract. The analysis indicated that $100 \mathrm{~g}$ of tofuyo extract contains $47 \mathrm{kcal}$ of energy, $88.8 \mathrm{~g}$ of water, $1.0 \mathrm{~g}$ of protein, $0 \mathrm{~g}$ of lipid, $6.9 \mathrm{~g}$ of carbohydrate, $1.2 \mathrm{~g}$ of ash, $420 \mathrm{mg}$ of sodium, $28 \mathrm{mg}$ of potassium, $6 \mathrm{mg}$ of calcium, $13 \mathrm{mg}$ of magnesium, $0 \mathrm{mg}$ of phosphorus, $0.1 \mathrm{mg}$ of iron, $0 \mathrm{mg}$ of zinc, $0.01 \mathrm{mg}$ of copper, $0.01 \mathrm{mg}$ of manganese, $0 \mathrm{mg}$ of vitamin $B_{1}, 0.02 \mathrm{mg}$ of vitamin $B_{2}, 0.02 \mathrm{mg}$ of vitamin $B_{6}$, $0 \mathrm{~g}$ of soluble fiber, $0 \mathrm{~g}$ of insoluble fiber, $0 \mathrm{~g}$ of total dietary fiber, $1.1 \mathrm{~g}$ of sodium chloride equivalent and $2.1 \mathrm{~g}$ of alcohol (Table I).

In addition, the amino acid analysis indicated that $100 \mathrm{~g}$ of tofuyo extract contain $21 \mathrm{mg}$ of arginine, $56 \mathrm{mg}$ of lysine, $22 \mathrm{mg}$ of histidine, $48 \mathrm{mg}$ of phenylalanine, $38 \mathrm{mg}$ of tyrosine, $70 \mathrm{mg}$ of leucine, $45 \mathrm{mg}$ of isoleucine, $11 \mathrm{mg}$ of methionine, $48 \mathrm{mg}$ of valine, $52 \mathrm{mg}$ of alanine, $43 \mathrm{mg}$ of glycine, $58 \mathrm{mg}$ of proline, $213 \mathrm{mg}$ of glutamic acid, $43 \mathrm{mg}$ of serine, $35 \mathrm{mg}$ of threonine, $101 \mathrm{mg}$ of aspartic acid, $6 \mathrm{mg}$ of tryptophan and $10 \mathrm{mg}$ of cysteine and cystine (Table II).

\section{Discussion}

In the in vitro analysis, tofuyo did not show any direct inhibitory or disruptive effects against influenza virus (6). However, alleviation of influenza symptoms, including an increase in the survival rate and suppression of weight loss, was observed in the animal experiment performed in this study, suggesting that indirect protective effects of tofuyo occur in mice. Due to the fact that there was no significant difference between the tofuyo extract-treated and control groups, tofuyo extract was considered to have no inhibitory 
Table I. Nutrient component analysis of tofuyo extract.

\begin{tabular}{|c|c|c|}
\hline Nutrient & Value/100 g of tofuyo extract ${ }^{\mathrm{a}}$ & Method \\
\hline Energy & $47 \mathrm{kcal}$ & Modified Atwater method ${ }^{\mathrm{b}}$ \\
\hline Water & $88.8 \mathrm{~g}$ & Reduced pressure and drying by heating method ${ }^{c}$ \\
\hline Protein & $1.0 \mathrm{~g}$ & Modified Kjeldahl method (protein conversion factor 5.71) \\
\hline Lipid & $0 \mathrm{~g}$ & Soxhlet extraction method \\
\hline Carbohydrate & $6.9 \mathrm{~g}$ & Subtraction method $^{\mathrm{d}}$ \\
\hline Ash content & $1.2 \mathrm{~g}$ & Direct ashing method \\
\hline Sodium & $420 \mathrm{mg}$ & Atomic absorption method \\
\hline Potassium & $28 \mathrm{mg}$ & Atomic absorption method \\
\hline Calcium & $6 \mathrm{mg}$ & Atomic absorption method \\
\hline Magnesium & $13 \mathrm{mg}$ & Atomic absorption method \\
\hline Phosphorus & $0 \mathrm{mg}$ & Vanadic and molybdic acid absorption photometry \\
\hline Iron & $0.1 \mathrm{mg}$ & Atomic absorption method \\
\hline Zinc & $0 \mathrm{mg}$ & Atomic absorption method \\
\hline Copper & $0.01 \mathrm{mg}$ & Atomic absorption method \\
\hline Manganese & $0.01 \mathrm{mg}$ & Atomic absorption method \\
\hline Vitamin $\mathrm{B}_{1}$ & $0 \mathrm{mg}$ & High-performance liquid chromatographic method \\
\hline Vitamin $\mathrm{B}_{2}$ & $0.02 \mathrm{mg}$ & High-performance liquid chromatographic method \\
\hline Vitamin $\mathrm{B}_{6}$ & $0.02 \mathrm{mg}$ & Microbial quantification method \\
\hline Provide soluble fiber & $0 \mathrm{~g}$ & Modified Prosky method \\
\hline Insoluble dietary fiber & $0 \mathrm{~g}$ & Modified Prosky method \\
\hline Total amount of food fiber & $0 \mathrm{~g}$ & Modified Prosky method \\
\hline Corresponding value of salt & $1.1 \mathrm{~g}$ & Corresponding value from sodium \\
\hline Alcohol & $2.1 \mathrm{~g}$ & Gas chromatography \\
\hline
\end{tabular}

aZero means either $<0.1$ of the minimum quantity in food composition reported previously (5) or undetectable; benergy conversion factor was 4 (protein), 9 (lipid), 4 (carbohydrate), 2 (food fiber) and $7.1 \mathrm{kcal} / \mathrm{g}$ (alcohol); ${ }^{\mathrm{c}}$ water quantity was calculated by the dry weight method with subtraction of the alcohol quantity; ${ }^{\mathrm{d}}$ carbohydrate was calculated by subtraction of alcohol.

Table II. Amino acid analysis of tofuyo extract.

\begin{tabular}{|c|c|c|}
\hline Amino acid & Value (mg/100 g tofuyo extract) & Method \\
\hline Arginine & 21 & Automatic analysis method for amino acids \\
\hline Lysine & 56 & Automatic analysis method for amino acids \\
\hline Histidine & 22 & Automatic analysis method for amino acids \\
\hline Phenylalanine & 48 & Automatic analysis method for amino acids \\
\hline Tyrosine & 38 & Automatic analysis method for amino acids \\
\hline Leucine & 70 & Automatic analysis method for amino acids \\
\hline Isoleucine & 45 & Automatic analysis method for amino acids \\
\hline Methionine & 11 & Automatic analysis method for amino acids \\
\hline Valine & 48 & Automatic analysis method for amino acids \\
\hline Alanine & 52 & Automatic analysis method for amino acids \\
\hline Glycine & 43 & Automatic analysis method for amino acids \\
\hline Proline & 58 & Automatic analysis method for amino acids \\
\hline Glutamic acid & 213 & Automatic analysis method for amino acids \\
\hline Serine & 43 & Automatic analysis method for amino acids \\
\hline Threonine & 35 & Automatic analysis method for amino acids \\
\hline Aspartic acid & 101 & Automatic analysis method for amino acids \\
\hline Tryptophan & 6 & High-performance liquid chromatographic method \\
\hline Cysteine and cystine & 10 & $\begin{array}{l}\text { Automatic analysis method for amino acids (performic } \\
\text { acid oxidation }+ \text { hydrochloric acid hydrolysis) }\end{array}$ \\
\hline
\end{tabular}


effect on influenza virus infection, while it contributes to the maintenance of health following infection. This hypothesis is supported by the results of this study, indicating that tofuyo contains proteins, carbohydrates, vitamins and minerals. Consequently, tofuyo has health-promoting effects. In addition, amino acid analysis demonstrated that tofuyo is rich in glutamic and aspartic acid; therefore, umami components evidently remained in the extract.

In a previous study, tofuyo extract was found to contain di- and tri-peptides (1). In addition, short peptides from soybean extract were shown to be absorbed via the intestine and reach a higher concentration in the blood $(7,8)$. Therefore, such short peptides in tofuyo extract may act in the blood and show anti-influenza virus effects. Furthermore, the anti-oxidative properties of tofuyo (9) may contribute to the defense against influenza virus infection-induced oxidative stress. The induction of immune functions in tofuyo extract-treated animals is an additional potential anti-influenza virus mechanism. However, to fully elucidate the anti-influenza effect of the tofuyo extract additional studies are required.

\section{Acknowledgements}

This study was supported by a Grant-in-Aid from the Fuji Foundation for Protein Research (http://www.fujioil.co.jp/ daizu/). Part of this study was presented at various conferences organized by the Fuji Foundation for Protein Research in 2010 and 2011. The Fuji Foundation for Protein Research kindly granted permission to publish this study. Data included in this study have partly been reported in conference proceedings (6).

\section{References}

1. Kuba M, Tanaka K, Tawata S, Takeda Y and Yasuda M: Angiotensin I-converting enzyme inhibitory peptides isolated from tofuyo fermented soybean food. Biosci Biotechnol Biochem 67: 1278-1283, 2003.

2. Yasuda M, Matsumoto T, Sakaguchi M and Kinjo S: Production of tofuyo using combination of red and yellow kojis. Nippon Shokuhin Kagaku Kogaku Kaishi 42: 38-43, 1995 (In Japanese).

3. Sakudo A, Baba K, Tsukamoto M, Sugimoto A, Okada T, Kobayashi T, Kawashita N, Takagi T and Ikuta K: Anionic polymer, poly(methyl vinyl ether-maleic anhydride)-coated beads-based capture of human influenza A and B virus. Bioorg Med Chem 17: 752-757, 2009.

4. Dobashi N, Yasui A and Wataanbe T: Basics of food analysis. In: Nutrition and Food Science Dictionary (The Japanese Society of Nutrition and Food Science). Yasumoto K, Takeuchi M, Yasui A and Watanabe T (eds). Kenpakusha, Tokyo, pp1-58, 2006.

5. Kagawa Y: Explanation for standard tables of food composition. In: Standard Tables of Food Composition in Japan (Fifth Revised and Enlarged Edition). Kagawa Education Institute of Nutrition, Tokyo, pp2-3, 2010.

6. Sakudo A and Sesoko M: Effects of tofuyo (fermented soybean food) extract on influenza virus. Soy Protein Res (Japan) 14: 146-149, 2011.

7. Claft IL, Geddes D, Hyde CW, Wise IJ and Matthews DM: Absorption and malabsorption of glycine and glycine peptides in man. Gut 9: 425-437, 1968.

8. Chun H, Sasaki M, Fujiyama Y and Bamba T: Effect of peptide chain length on absorption and intact transport of hydrolyzed soybean peptide in rat intestinal everted sac. J Clin Biochem Nutr 21: 131-140, 1996.

9. Yasuda M and Morita M: Food-chemical research on tofu curd. Decomposition and antioxidative property of protein in maturation process. J Jpn Soc Nutr Food Sci 52: 303, 2010. 